
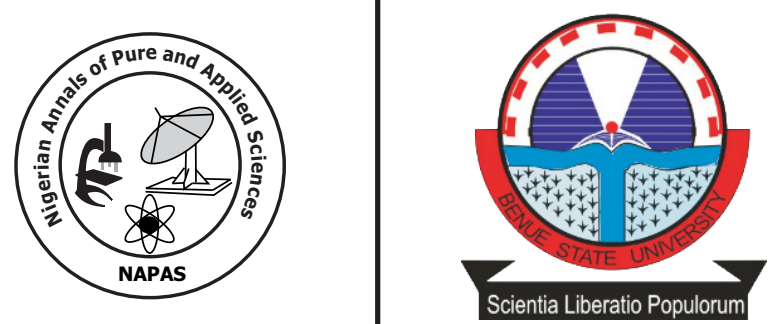

\title{
Molecular Identification of Green Algae, Spirogyra Porticalis, along Parts of River Kaduna and its Potential for Singlecell Protein (SCP) Production
}

\author{
Haroun, A. A ${ }^{1}$, Matazu, I. K ${ }^{2}$, Abdulhamid, $\mathbf{Y}^{3}$. and Sani, J' \\ 1. Department of Biological Sciences, Nigerian Defence Academy, Kaduna. \\ 2. Department of Biochemistry, Umaru Musa YarAdua University, Katsina. \\ 3. Department of Biological Sciences, Umaru Musa Yar Adua University, Katsina. \\ *Correspondence Author: aliahmharoun@yahoo.com
}

\begin{abstract}
The freshwater alga spirogyra porticalis, a filamentous chlorophyte, was collected and identified on the basis of morphology and molecular characteristics. The nutritional composition of the Alga (protein, carbohydrate, moisture, fat, ash) were determined using the AOAC, Official Methods of Analysis. The components of Single Cell Protein (SCP) were determined using method of proximate analysis. The total content of protein (\% dry weight) ranged from $12.46-16.89 \%$, carbohydrate from $34.72-39.25 \%$, moisture from $12.97-16.75 \%$, fat from 20.17-22.03\%, ash from 10.78-15.98\%. The result revealed that this Macroalga has an appreciable amount of protein, carbohydrate, moisture, fat, and ash. Amino acids composition determines the protein quality of Algae. Hence, the amino acids present in the algal sample were extracted and estimated using an automated amino acids Analyzer. The results have shown the presence of the following amino acids; Leu, Lys, Ile, Phe, Val, His, Arg, Met, Trp, Thr, Pro, Tyr, Gly, Glu, Asp, Cys, Ser, Ala. The essential amino acids (Leu, Lys, Ile, Phe, Val, His, Arg, Met, Trp, Thr) profile of the alga as compared with conventional protein sources and the WHO/FAO reference pattern of essential amino acids (g per 100 protein), reveals that the levels of the essential amino acids in the alga were either similar to or greater than the levels of the same amino acids in the reference foods and WHO/FAO reference pattern. Thus, results of the present study shows that S.porticalis is a potential source of single cell protein, and may be of use to the food industry as a source of ingredients with high nutritional value. S. porticalis can provide a dietary alternative due to its nutritional value and its commercial value can be enhanced by improving the quality and expanding the range of freshwater macroalgae based products.
\end{abstract}




\section{Introduction}

The term single-cell protein (SCP) is used to describe protein derived from pure or mixed cultures of microorganisms such as yeast, fungi, algae and bacteria which are used as a substitute for the conventional protein sources exploited for human and animal consumption (Najafpour, 2007).

Population growth combined with increasingly limited resources of arable land and fresh water has resulted in a need for alternative protein sources. Nigeria with a population of approximately 196 million people, in a million $\mathrm{Km}^{2}$, needs to brace up to such challenges, and exploit all sources of food production, especially protein production. Macroalgae (seaweed) and microalgae are examples of under-exploited "crops". Algae do not compete with traditional food crops for space and resources (Stephen et al., 2017).

The global population is expected to increase by over a third ( 2.3 billion people) by 2050 , requiring an estimated $70 \%$ increase in food production (Godfray et al., 2010). A combination of improved agricultural food production methods and an increase of average per capita income have led to a decrease in global hunger over the last half-century, despite a doubling of the world's population (Godfray et al., 2010). The term SCP was coined by Carol L. Wilson in 1966.Single cell protein is dried cells of microorganism, which are used as protein supplement in human foods or animal feeds (Rasoul-Amini et al., 2009).

Besides high protein content (about 60$82 \%$ of dry cell weight), SCP also contains fats, carbohydrates, ash ingredients, moisture, nucleic acids, vitamins andminerals. Another advantage with SCP isthat it is rich in certain essential amino acids like lysine and methionine which are limiting in most plant and animal foods (Jamel et al., 2008).

Generally, products from macroalgae are considered as low calorie foods with high contents of minerals, vitamins, proteins and carbohydrates (Kumari et al., 2009). Most of the figures published in the literature on concentration of algal proteins, dominantly enzymatic proteins, are based on estimates of so called crude proteins, commonly used in evaluating food and feed. These figures are the result of hydrolysis of the algal biomass and estimation of the total nitrogen (Rasoul-Aminiet al., 2009).

Algae synthesize all of the amino acids necessary for protein synthesis and some unique ones too, including D-alanine, D-glutamine and $\beta$ amino acids are found in microcystin, a toxic principle in the cyanobacterium Microcystis aeruginosa.

Algae are generally regarded as a viable protein source, with EAA composition meeting FAO requirements and they are often on par with other protein sources, such as soybean and egg (Fleurence 1999). The advantages in using algae include simple cultivation, effective utilization of solar energy, faster growth and high protein and nutrient content (Rajaet al., 2008).

\section{Materials and methods}

Kaduna, capital of Kaduna state, lays at Latitude 10.2N and Longitude 7.23E. It has a huge human population and a lot of both Industrial and Agricultural activities. This has led to great amount of wastes, especially from large number of textile industries, being dumped in neighbouring water bodies, one of which is River Kaduna (Ohioma et al., 2009). The Algal samples collected from River Kaduna were transferred to labeled transparent 1 litre plastic bottles. The samples were transported to laboratory for species identification. The algal species was washed with distilled water to remove macro/microscopic contaminations as described by Tipnee et al., (2015).

The algasample was placed as a thin smear of the sample on a glass slide with a few drops of water and covered with a cover slip. The algal sample was observed under light microscope and photographs were taken with attached digital camera. The Alga was identified by comparing the morphology with taxonomic keys and literature as given by Prescott (2007). According to its morphology and macro/microscopic observations, it was identified as Spirogyra porticalis

\section{DNAExtraction}

The DNA of Spirogyra porticalis macroalga was extracted using Bioland mini prep extraction kits. A hundred $\mathrm{mg}$ of the plant tissue (microalgae) was grounded in a $2.0 \mathrm{~mL}$ microcentrifuge tube, $600 \mu 1$ Buffer PL1 was added; The mixture was incubated at $65^{\circ} \mathrm{C}$ for 10 min and was mixed twice during incubation by inverting the tube, A $140 \mu 1$ Buffer PL2 was added and mixed by vortexing for $10 \mathrm{~s}$ followed by centrifugation at $11,000 \mathrm{rpm}$ for $10 \mathrm{~min}$. The supernatant was carefully transferred to a clean $2.0 \mathrm{~mL}$ tube.

18S rDNA primer sets purchased from Bioneer, SS5 (forward, 5'-GGTGATCCTGCCAGTA GTCATATGCTTG-3') and SS3 (reverse, 5 '-G AT C C T T C C GCA G GT T C A C C TAC GGAAACC- 3 ') were used for $\mathrm{PCR}$ reaction 
(Grzebyk et al., 1995). Each PCR sample consist of a solution of DNA template (10-20 $\mu \mathrm{g}), 1 \mu \mathrm{l}$ of each primer (Bioneer), with a master mix which consist of Taq polymerase, dNTPs, buffer and cations. The best PCR conditions, based on PCR product quality results were determined for the microalgae sample. The first uses $50^{\circ} \mathrm{C}$ for 1 minute and the second run was at $60^{\circ} \mathrm{C}$ for 2minutes.

Following PCR reactions, the quality of the PCR products were determined through $1 \%$ standard Agarose gel electrophoresis. The DNA was isolated from the gel using Bioland mini prep extraction kits according to the manufacturer's instructions. The concentration of the DNA that was isolated was determined before proceeding for sequence analysis. The DNA obtained was sequenced, using BECKMAN COULTER CEQ 2000XL DNA analysis system and the sequences obtained were compared for homology against sequences on the GenBank at the NCBI website for Identification of the Alga.

\section{Sample preparation}

A total of 50 grams of wet weight of Spirogyra porticalis was harvested. The alga was rinsed with fresh water to remove sand and debris and again with distilled water and manually sorted to remove epiphytes (Tipnee et al., 2015).

The sample was dried using the oven drying technique. Thick slurry of wet biomass was placed in an oven overnight at temperature of $60^{\circ} \mathrm{C}$ for 12 hours as described by Lee, et al., (2010).

The dried biomass was crushed using a mortar and pestle and the dried algal powder stored indesiccators to avoid absorption of moisture prior to use.

\section{Protein measurement}

The standard AOAC (2006) procedure was used for protein analysis. Kjeldahl nitrogen method is one of the most widely recognized methods employed for crude protein determination. Crude protein was determined as total nitrogen by a conversion factor 6.25 . This method involves the three (3) stages, namely, Digestion, Distillation and Titration.

\section{Determination of moisture content}

Moisture content is the amount of moisture present in a food product. This test is based on LOD (Loss on drying) at an oven temperature of $105^{\circ} \mathrm{C}$. Besides water, other matter volatile at $105^{\circ} \mathrm{C}$ will also be lost.

A dried cooled platinum dish was weighed $\left(\mathrm{w}_{1}\right)$ and $3 \mathrm{~g}$ of the test sample was introduced into the dish and weighed accurately $\left(\mathrm{w}_{2}\right)$. The dish was transferred and its content into an oven at $105^{\circ} \mathrm{C}$ to dry for about 3 hours and the dish was removed and weighed $\left(\mathrm{w}_{3}\right)(\mathrm{AOAC}, 2006)$.

\section{Determination of Fat content}

$2 \mathrm{~g}$ of the sample was weighed into a boiling tube. $10 \mathrm{ml}$ of conc. $\mathrm{HCl}$ was added and put in a boiling water bath until solid particles dissolve and until mixture becomes brown. It was then taken off and cooled, then transferred into a separating funnel. $10 \mathrm{ml}$ of ethanol and $30 \mathrm{ml}$ of diethyl ether were added and shaken to dissolve; it was then allowed to stand for some minutes so as to separate.A clean dried conical flask $\left(\mathrm{w}_{1}\right)$ was weighed and the ether layer was transferred into the flask. The extraction was repeated twice with $25 \mathrm{ml}$ of diethyl ether and the extract was evaporated in a water bath. The fat was dried at $105^{\circ} \mathrm{C}$ in an oven, cooled and weighed $\left(\mathrm{w}_{2}\right)$ (AOAC, 2006).

\section{Determination of Ash content}

A dry cool platinum dish was accurately weighed as $\left(\mathrm{w}_{1}\right)$ and about $3 \mathrm{~g}$ of the food sample was spread evenly in the dish and weighed as $\left(\mathrm{w}_{2}\right)$. If the substance is moist, dry using water bath and char over hot plate in the fume cardboard until no more sooth is given off. Then it was transferred using a pair of tongs into a muffle furnace at $550^{\circ} \mathrm{C}$ until fully ashed (colour changes to gray) and weigh as $\left(\mathrm{w}_{3}\right)$ (AOAC, 2006). Also determined were, Total carbohydrate, Amino Acid Profile and Nitrogen Content.

\section{Statistical Analysis}

All the values or readings are the result of mean of three replicates. Data is reported as mean \pm standard deviation (SD). Statistical analyses were performed using Microsoft Excel.

\section{Results \\ Morphological Identification of Alga}

The green alga was identified based on their morphology. The morphology of algal specimen was studied carefully and the specimen was identified as Spirogyra porticalis (Müller) Dumortier. Figure 1, show the morphology of $S$. porticalisobserved under a light microscope. 


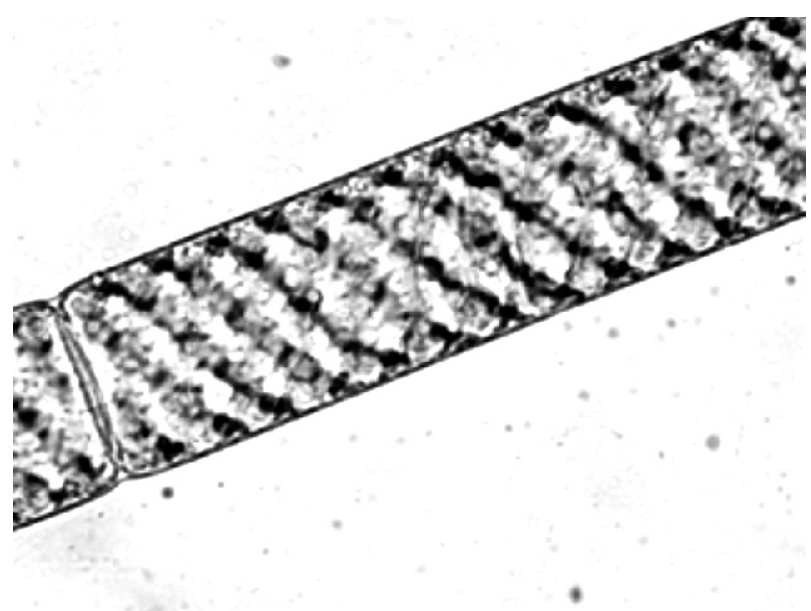

Figure 1(a) Microscopic picture of macro algae Spirogyra porticalis (X10 Magnification)

\section{Molecular Identification}

DNA extraction of Spirogyra porticalis-

The genomic DNA was extracted and quantified. DNA concentration ranged from 1-10 $\mathrm{gg}$. DNA band that showed high molecular weight and brightness were selected for PCR analysis.

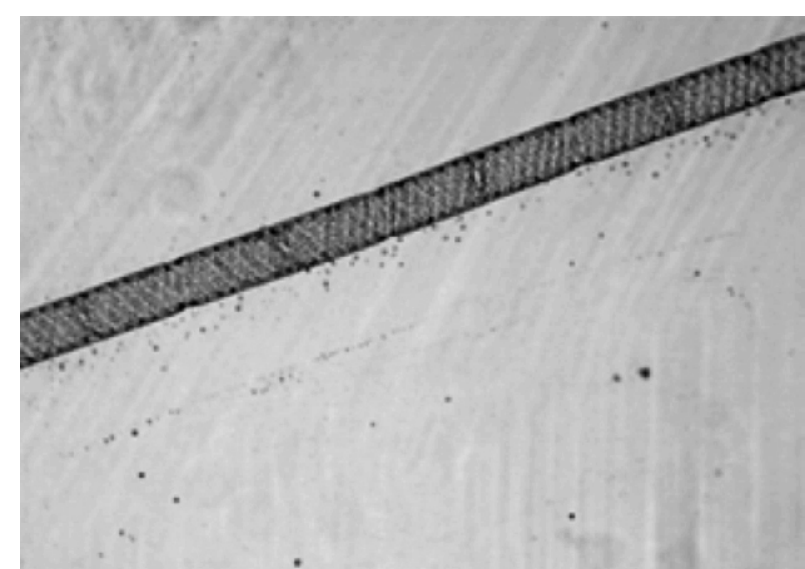

Figure 1(b) - Microscopic picture of macro algae Spirogyra porticalis (X40 Magnification)

\section{Gel electrophoresis of the PCR product}

The run made, resulted in a double band size of $0.3 \mathrm{~kb}$ and $1.8 \mathrm{~kb}$ on lane $\mathrm{B}$ when matched with the DNA molecular weight ladder on lane $A$ as presented in Plate 4.1

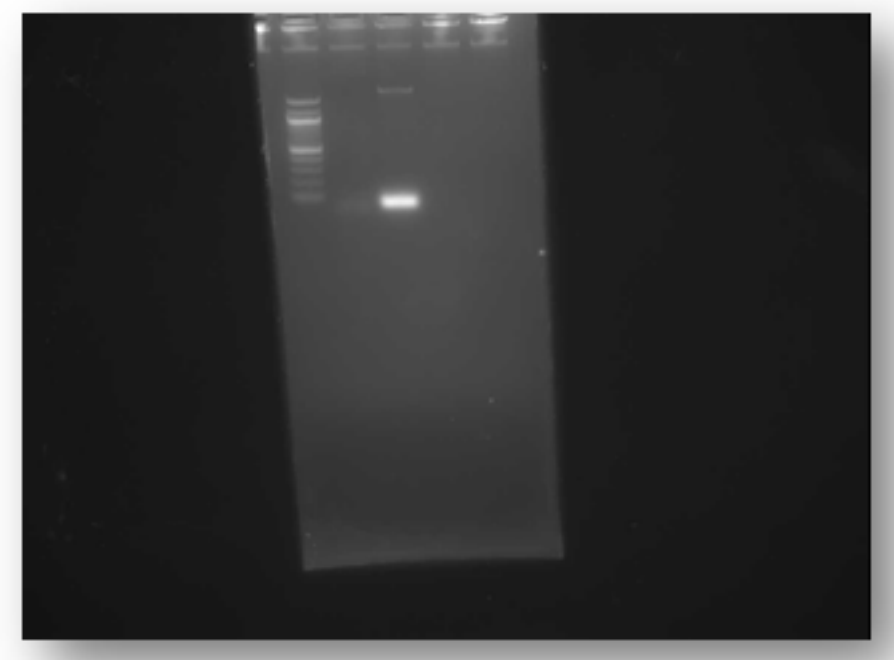

Plate 4.1 Showing Gel electrophoresis results of Spirogyra porticalis PCR products Legend-

Lane A: DNA molecular weight ladder.

Lane B: DNA Sample

\section{Sequencing and BLAST analysis}

Upon Sequencing and BLAST revealed 95\% identity with Spirogyra porticalis with an accession number: KC 701473.1 18S ribosomal RNAgene.

\section{Nutritional Constituents (\%) Of Green Algae Spirogyra porticalis}

The chemical analyses of Spirogyra porticalis from River Kaduna, revealed it's nutritive value constituents as shown in Table 1. Protein content ranged between $12.46 \%$ and $16.89 \%$. Carbohydrate content from $34.72 \%$ to
$39.25 \%$ fat content ranged from 20.17 to $22.03 \%$, moisture content ranged from 12.97 to $16.75 \%$, and ash content ranged from 10.78 to $15.98 \%$.

\section{Determination of Amino Acid Profile}

The known sample was dried to constant weight, defatted, hydrolyzed, evaporated in a rotary evaporator and loaded into the Applied Biosystems PTH Amino Acid Analyzer.

The results have shown the presence of both essential and non-essential amino acids, as presented in Table 2. 
Table 1: Nutritional Constituents (\%) Of Spirogyra porticalis

\begin{tabular}{lccc}
\hline S/NO & Parameter & Mean \pm SD (\%) & Range (\%) \\
\hline 1 & Protein & $14.68 \pm 2.21$ & $12.46-16.89$ \\
2 & Fat & $21.02 \pm 0.94$ & $20.17-22.03$ \\
3 & Moisture & $14.75 \pm 1.89$ & $12.97-16.75$ \\
4 & Ash & $13.23 \pm 2.61$ & $10.78-15.98$ \\
5 & Total carbohydrate & $36.32 \pm 2.53$ & $34.72-39.25$ \\
\hline
\end{tabular}

Table 2: Amino Acids Profile of Green Alga Spirogyra porticalis

\begin{tabular}{lll}
\hline S/NO & Amino Acids & Concentration: g/100g protein \\
\hline 1 & Leucine $(\text { Leu })^{*}$ & 8.58 \\
2 & Lysine* & 6.52 \\
3 & Isoleucine $(\boldsymbol{I l e})^{*}$ & 5.20 \\
4 & Phenylalanine $(\boldsymbol{P h e})^{*}$ & 4.16 \\
5 & Tryptophan $(\boldsymbol{T r} \boldsymbol{p})^{*}$ & 1.10 \\
6 & Valine $\boldsymbol{V a l}()^{*}$ & 5.26 \\
7 & Methionine $(\boldsymbol{M e t})^{*}$ & 1.60 \\
8 & Proline $(\boldsymbol{P r o})$ & 2.50 \\
9 & Arginine $(\boldsymbol{A r g})^{*}$ & 6.02 \\
10 & Tyrosine $(\boldsymbol{T y r})$ & 3.96 \\
11 & Histidine $(\boldsymbol{H i s})^{*}$ & 1.53 \\
12 & Cystine $(\boldsymbol{C y s})$ & 0.24 \\
13 & Alanine $(\boldsymbol{A l a})$ & 6.82 \\
14 & Glutamic acid $(\boldsymbol{G l u})$ & 12.43 \\
15 & Glycine $(\boldsymbol{G l y})$ & 3.80 \\
16 & Threonine $(\boldsymbol{T h r})^{*}$ & 4.44 \\
17 & Serine $(\boldsymbol{S e r})$ & 4.59 \\
18 & Aspartic acid $(\boldsymbol{A s p})$ & 9.86 \\
\hline
\end{tabular}

\section{Key: *Essential amino acids}

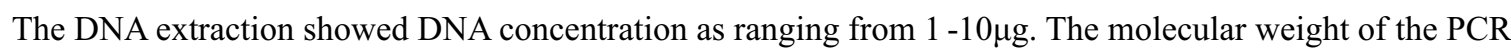
product was $1.8 \mathrm{~kb}$ using a set of $18 \mathrm{~S} \mathrm{r}$ DNA primer sets. This is consistent with the result of Reynaldo, (2012). Sequencing and BLAST revealed 95\% identity with Spirogyra porticalis $18 \mathrm{~S}$ ribosomal RNA gene.

\section{Discussion}

The freshwater alga used in this study was identified as Spirogyra porticalis filamentous green alga. The macroalgae, $S$. porticalis green algae, commonly available in River Kaduna, was analyzed for its nutritional and amino acids composition. The nutritional and amino acids composition of $S$. porticalis reveals that this macroalgae has an appreciable amount of dietary protein, carbohydrate, moisture, fat and ash ingredient which are the components of single cell protein $(\mathrm{SCP})$.

The amino acid composition shows it as rich in Glutamic acid (12.4g/100g protein). Study of the amino acid profile of this green alga, has shown that eight amino acids occurred in high concentration in all of them. These were Lysine,(8.58 g/100g protein), Isoleucine(5.20 $\mathrm{g} / 100 \mathrm{~g}$ protein), Aspartic acid $(9.86 \mathrm{~g} / 100 \mathrm{~g}$ protein), Arginine (6.02). Leucine (6.52 g/100g protein), Alanine $(6.82 \mathrm{~g} / 100 \mathrm{~g}$ protein), Valine $(5.26 \mathrm{~g} / 100 \mathrm{~g}$ protein) cystine is the least in all the assessedamino acids $(0.24 \mathrm{~g} / 100 \mathrm{~g}$ protein).

The essential Amino acid profile of the alga as compared with conventional protein sources and the WHO/FAO reference pattern of essential amino acids (g per 100 protein), reveals that the levels of the essential amino acids in the alga were either similar to or greater than the levels of the same amino acids in the reference foods and WHO/FAO reference pattern (WHO/FAO, 2013).

Therefore algae as a protein source can readily substitute for egg or other animal protein. Their amino acid profile is far superior to that of soybean and to that of other plant sources when considering the essential amino acid content. Searching for algae isolates with high rate of biomass potential with essential amino acids 
could expand the scope of source of relevant food supplements for humans and animal feed.

\section{References}

AOAC (Association of Official Analytical Chemicals) (2006).Official Method of Analysis of the AOAC (W. Horwitz Editor Eighteen Edition, Washington; D. C., AOAC.

Fleurence, J. Seaweed proteins: Biochemical, nutritional aspects and potential uses. Trends Food Science Technology.1999, 10, 25-28.

Food and Agriculture Organization. Food Balance Sheets; Food and Agriculture Organisation of the United Nations: Rome, Italy, 2013.

Godfray, H C, Beddington J R, Crate I R, Haddad L, Lawrence D and Thomas S M (2010). Food Secrity; the challenges of feeding 9 billion people. Science. 2010 Feb 12; 377(5967): 812- 8. Epub 2010. Jan 28.

Grzebyk, D., Sako, Y. and Berland, B. (1998). Phylogenetic analysis of nine species of Prorocentrum (dinophyceae) inferred from $18 \mathrm{~s}$ ribosomal DNA sequences, morphological comparisons, and description of Prorocentrumpanamensis sp. nov.Journal of Phycology, 34(6): 1055-1068.

Jamel P.,Alam M Z. and Umi N (2008). Media Optimization for bio proteins production from cheaper carbon source.Journal of Engineering, Science and Technology. 3 (2) 124-130.

Kumari, P. Kumar, M. Gupta, V. Reddy, C. R. K. and Jha, B. (2009). Tropical marine macroalgae as potential sources of nutritionally important PUFAs. Food Chem., 120: 749-757

Lee, J., Yoo, Jun, S., Ahn, C. and Oh, H. (2010).Comparison of several methods for effective lipid extraction from microalgae. Bioresources Technology, 101(1): 575-7.

Najafpour, G. D. 2007. Single Cell Protein. In: Biochemical Engineering and Biotechnology. Pp. 332-341. Amsterdam, The Netherland: Elsevier.

Ohioma A I, Luke N O and Amraibure O (2009).

Studies on the Pollution Potential of Wastewater from Textile Processing Factories in Kaduna, Nigeria.Journal of Toxicology and Environmental Health Science.Vol.1 (2). 034-037. July 2009.

Prescott, G. W., (2007). Algae of western Great lakes Area. $9^{\text {th }}$ edition. Wiley and sons, New York.

Raja RS, Hemaiswarya NA.Kumar, Sridhar S and Rengasamy R, "A perspective on biotechnological potential of micro algae", Critical Review of Microbiology, 2008, 34,77-88.

Rasoul-Amini, S., Ghasemi, Y., Morowvat, M. H. \& Mohagheghzadeh, A. 2009. PC Ramplification of $18 \mathrm{~S}$ rRNA, Single cell protein production and fatty acid evaluation of some naturally isolated microalgae. FoodChemistry, 116(1), 129-136.

Reynaldo, M. U. (2012). Identification of algal strains by PCR amplification and evaluation of their fatty acid profiles for biodiesel production. (Master"s thesis, Louisiana State University and Agricultural and

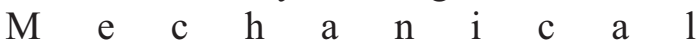
College).https://etd.Isu.edu/docs/availabl e/etd-01042012-150704/unrestricted/ Thesis.pdf.

Tipnee, S.Ramaraj, R. Unpaprom, Y. (2015) Nutritional Evaluation of Edible Freshwater Green Macroalga Spirogyravarians, Emerging Life Science Research (2015)1(2):1-7. 